Details of six infants with cardiac conduction disorders

\begin{tabular}{|c|c|c|c|c|c|c|}
\hline $\begin{array}{l}\text { Case } \\
\text { No }\end{array}$ & Sex & Feeding & $\begin{array}{l}\text { Birth } \\
\text { weight }(\mathrm{g})\end{array}$ & $\begin{array}{l}\text { Age at } \\
\text { presentation }\end{array}$ & ECG abnormality & Treatment \\
\hline $2^{*}$ & $\underset{\mathrm{F}}{\mathrm{M}}$ & $\begin{array}{l}\text { Breast } \\
\text { Breast }\end{array}$ & $\begin{array}{l}2840 \\
3460\end{array}$ & $\begin{array}{l}2 \text { weeks } \\
11 \text { days }\end{array}$ & $\begin{array}{l}\text { Supraventricular tachycardia } \\
\text { Supraventricular tachycardia with } \\
\text { varying P-R intervals, reciprocal } \\
\text { beats, and probable retrogradely } \\
\text { conducting accessory pathway }\end{array}$ & $\begin{array}{l}\text { Digoxin } \\
\text { Digoxin }\end{array}$ \\
\hline 3 & $\mathrm{~F}$ & Breast & 3430 & 3 weeks & $\begin{array}{l}\text { Supraventricular tachycardia and type } \\
\text { A Wolff-Parkinson-White syndrome }\end{array}$ & $\begin{array}{l}\text { Intravenous digoxin }(0.125 \mathrm{mg}) \text { with no } \\
\text { effect, then DC shock of } 7 \cdot 5 \text { joules; } \\
\text { recurrence treated with intravenous }\end{array}$ \\
\hline 4 & F & Ostermilk & 3120 & 11 weeks & Sinus rhythm, Wolff-Parkinson-White & Propranolol $5 \mathrm{mg}$ thrice daily \\
\hline $5+$ & M & SMA Milk & 2800 & 5 weeks & $\begin{array}{l}\text { Sinoatrial block with a slow junctional } \\
\text { escape rhythm of } 60 \text { beats } / \text { min }\end{array}$ & $\begin{array}{l}\text { Digoxin, frusemide; further episodes } \\
\text { treated with } 0.1 \mathrm{mg} \text { atropine }\end{array}$ \\
\hline 6 & $\mathrm{~F}$ & National Dried Milk & 2890 & 4 weeks & $\begin{array}{l}\text { Sinoatrial block with slow junctional } \\
\text { escape rhythm of } 70 \text { beats } / \text { min }\end{array}$ & $\begin{array}{l}\text { Further episodes treated with } 0.1 \mathrm{mg} \\
\text { atropine }\end{array}$ \\
\hline
\end{tabular}

* Irregular heart rate noted in utero and persisted until first stage of labour.

+ Respiratory syncytial virus isolated from nasopharyngeal aspirate.

disordered autonomic ${ }^{4}$ activity rather than primary cardiac conducting system disease.

The last infant in our series now has generalised hypertonia and severe psychomotor retardation. This infant was previously well and ischaemic brain damage probably followed an episode of low cardiac output as a result of a tachyarrhythmia, which was probably secondary to pre-excitation.

These cases suggest strongly that cardiac arrhythmias can cause certain unexplained sudden infant deaths. Had a screening ECG been performed in the neonatal period (see accompanying paper) these episodes may have been prevented. Our findings support our contention that further study is necessary to identify the conduction disorders in infancy. It will then be necessary to identify those who need treatment and the appropriate treatment.
We are indebted to Drs A Franklin, L Haas, R Jones, D Kennaird, A D Milner, and D G Vulliamy, who treated these children and gave their permission and help in the reporting of these case histories.

Requests for reprints should be addressed to: Dr D P Southall, Dorset County Hospital, Princes Street, Dorchester, Dorset DT1 1TS.

\section{References}

James, T N, Circulation, 1976, 53, 1.

2 Guilleminault, C, et al, Lancet, 1976, 1, 1326

${ }^{3}$ Emery, J L, in Recent Advances in Paediatrics, No 5, ed D Hull. London, Churchill Livingstone, 1976.

4 Schwartz, P J, American fournal of Medicine, 1976, 60, 167.

\title{
Comparison of the antilipolytic effect of metoprolol, acebutolol, and propranolol in man
}

\author{
RAYMOND J NEWMAN
}

British Medical fournal, 1977, 2, 601-603

\section{Summary}

Metoprolol and acebutolol, two supposedly cardioselective beta-adrenoceptor antagonists, were tested in 11 healthy men against propranolol, a non-selective drug, for their effect on plasma free fatty acid concentrations before and after insulin. The fasting concentrations of free fatty acid were significantly reduced after acebutolol and propranolol, and their return to normal after insulin was delayed. Metoprolol had no significant effect on free fatty acid levels either before or after insulin. Although both selective and non-selective beta-blocking drugs should be expected to delay the return of free fatty acid values to normal after insulin, in contrast to propranolol and acebutolol, metoprolol had no such effect.

This suggests that metoprolol may not be as effective as

St James's University Hospital, Leeds 9

RAYMOND J NEWMAN, BSC, MB, house physician (now senior house surgeon) the other two drugs in controlling lipid metabolism during long-term treatment with beta-adrenoceptor antagonists.

\section{Introduction}

Besides their circulatory actions, the beta-adrenoceptor antagonists in common use have several metabolic effects, ${ }^{12}$ including the inhibition of lipolysis. ${ }^{3}$ Newer beta-blocking drugs, however, are claimed to be cardioselective-that is, their action is maximal on cardiac beta-adrenoceptors and less so on beta-adrenoceptors in other tissues.

The study reported here was designed to compare the effect on lipolysis of propranolol, a non-selective beta-adrenoceptor antagonist, with that of metoprolol and acebutolol, two drugs generally considered to be cardioselective. Lipolysis was initiated by an insulin-induced fall in the concentration of circulating free fatty acid.

\section{Patients and methods}

Eleven healthy male medical students, aged $20-23$ years, with no history of diabetes mellitus, hyperlipaemia, ischaemic heart disease, 
or obstructive airway disease were studied. They took no other drugs during the period of investigation. The design of this study was approved by the ethical committee of this hospital and all the volunteers gave informed consent.

Each volunteer received insulin on four occasions, once as control and once after a course of each of the three drugs. After the uneventful administration of a test dose of each drug propranolol (Inderal) $40 \mathrm{mg}$ twice daily, metroprolol (Lopressor) $50 \mathrm{mg}$ twice daily, or acebutolol (Sectral) $100 \mathrm{mg}$ twice daily was taken by mouth for 48 hours in a single-blind manner before each test session, with the last dose two hours before the start of the test. These doses were considered to be equipotent. ${ }^{4-8}$ In all cases the tests started at $9.00 \mathrm{am}$. The order of the studies was randomised and at least four days elapsed between tests.

After a 12-hour overnight fast each subject rested in a recumbent position and an indwelling venous catheter was inserted and kept patent by intermittent irrigation with $0.9 \%$ saline. After 30 minutes' stabilisation the first sample of blood was withdrawn, followed by a rapid intravenous injection of insulin $B P$ (Weddel Pharmaceuticals, London) $0 \cdot 1$ units $\mathrm{kg}$ body weight. Further samples were taken 30, 60 , and 120 minutes after the administration of the insulin, and the pulse rate was measured on each occasion.

Laboratory methods-Blood was collected into sodium ethelenediamine tetra-acetate for the measurement of free fatty acid by the method of Dole ${ }^{y}$ as modified by Trout et al. ${ }^{11}$ All analyses were performed in duplicate and the mean taken for statistical analysis.

Statistical methods-The plasma free fatty acid results were examined statistically in two different ways. Firstly, graphs of plasma free fatty acid versus time were plotted for each episode for each volunteer and the areas enclosed under the recovery phase of the curves computed. The areas obtained for each drug were then compared by Student's $t$ test. Secondly, each point in fig 1 was compared by Student's $t$ test for paired data. Significance was accepted at a $5 \%$ level of accuracy and both statistical techniques gave the same results.

\section{Results}

Plasma free fatty acid concentrations and pulse rate during the experiment are presented in figs 1 and 2 . The fasting concentration of free fatty acid was reduced after acebutolol $(\mathbf{P}<0.05)$ and propranolol $(P<0.05)$, and the return to normal after insulin was delayed with these two drugs $(P<0.005$ for propranolol and $P<0.0025$ for acebutolol). Neither drug significantly potentiated the fall in free fatty acid induced by the insulin and at no time was there a significant difference between the effects of the two drugs. Metoprolol had no significant effect on free fatty acid concentrations throughout the study, and its action was not significantly different from those of the

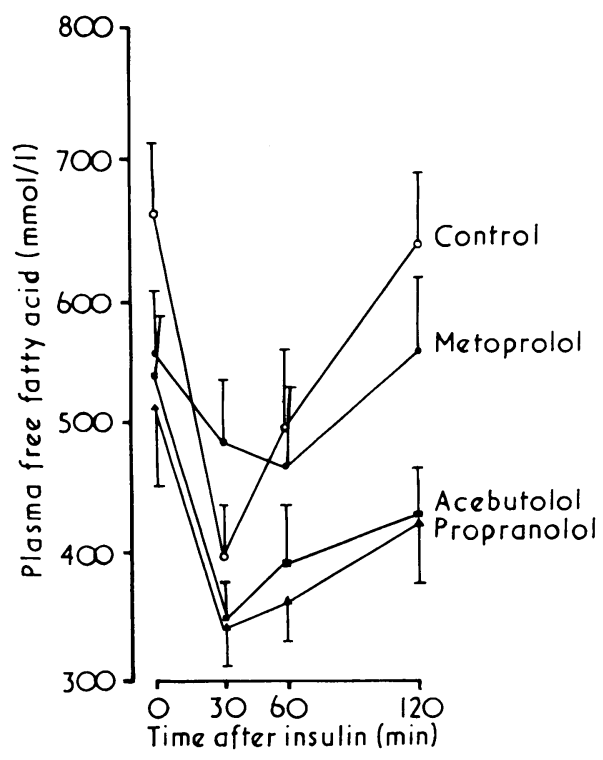

FIG 1-Effect of beta-adrenergic blockade on plasma free fatty acid levels after $0 \cdot 1$ unit insulin/ $\mathrm{kg}$ body weight. Each point represents mean ( \pm SE of mean) of at least seven values.

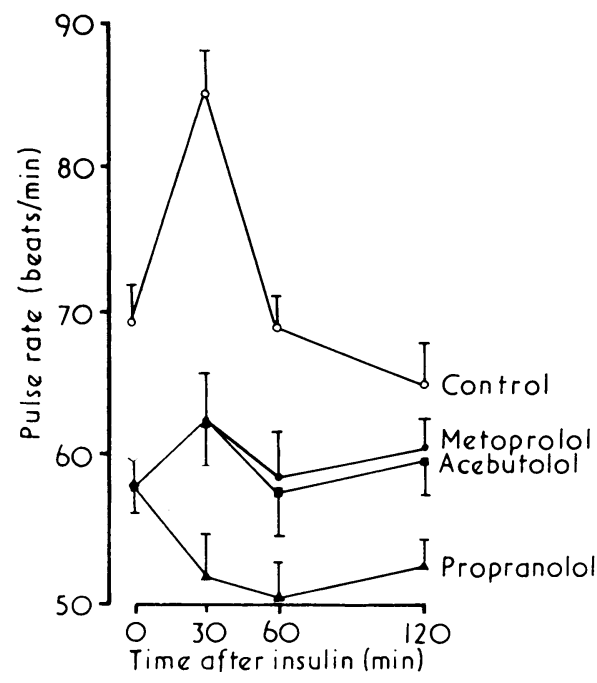

FIG 2-Effect of beta-adrenergic blockade on pulse rate after 0.1 units insulin $\mathrm{kg}$ body weight. Each point represents mean $( \pm \mathrm{SE}$ of mean) of 11 values.

other two drugs before the administration of the insulin. Free fatty acid concentrations after metoprolol were, however, significantly different from those after acebutolol and propranolol during the recovery part of the study $(P<0 \cdot 05)$.

All drugs reduced the resting pulse rate by the same amount and reduced or even abolished the tachycardia produced by the hypoglycaemia.

Side effects-One case of indigestion and one case of nausea and sweating were noted during the administration of propranolol. One volunteer reported slight wheezing while taking acebutolol. All volunteers reported that the subjective feelings of hypoglycaemia were reduced by all the drugs under investigation.

\section{Discussion}

In considering the clinical implications of these findings it must be borne in mind that the health of the fit young men to whom drugs were given in this trial contrasts strongly with that of the average patient for whom beta-adrenoceptor antagonists are prescribed.

The finding that propranolol reduced the fasting concentration of free fatty acid and delayed the return to normal after insulin has been reported. ${ }^{11}$

In man the sympathetically mediated release of free fatty acid is controlled via the beta $_{1}$ division of the sympathetic nervous system, ${ }^{3}$ and both the so-called selective and nonselective beta-adrenoceptor antagonists used in this experiment should therefore be expected to inhibit the release of free fatty acid and hence delay the return to normal concentrations after insulin. Even though metoprolol and acebutolol were administered in equipotent doses, however, their effects on the return of free fatty acid concentrations to normal differed significantly. Furthermore, values on metoprolol did not differ significantly from control values, and values on acebutolol did not differ significantly from those on the non-cardioselective drug propranolol.

These results differ from those of a study in the same volunteers in which blood glucose concentrations before and after the same doses of insulin were measured after the same courses of drugs as in this study. ${ }^{12}$ No significant difference was found between values after acebutolol and control values, but metoprolol and propranolol both delayed the return to normoglycaemia to a similar extent.

In this study the ability of acebutolol and propranolol to inhibit lipolysis was paralleled by their ability to inhibit the tachycardia induced by the hypoglycaemia. In the case of 
metoprolol, however, a dissociation between its lipolytic and cardiac actions was noted.

These results indicate therefore differences in the metabolic effects of metoprolol, acebutolol, and propranolol but give no insight into the mechanisms concerned.

Attempts to reduce blood lipid levels in patients with hyperlipaemia with beta-adrenoceptor antagonists have yielded inconsistent results. ${ }^{13}{ }^{14}$ Carruthers and Taggart ${ }^{15}$ have shown, however, that oxprenolol suppresses the rise in free fatty acid concentrations that occurs in response to stress. Prolonged treatment with beta-adrenoceptor antagonists might therefore serve to control lipid metabolism and minimise its atherogenic potential. To investigate this would require long-term studies and, as yet, none have been performed. The findings of this study therefore suggest that, should such a trial be undertaken, acebutolol and propranolol may show a greater therapeutic effect than metoprolol.

I thank Dr D Barnett, consultant physician to this hospital, for placing the facilities of his metabolic laboratory at my disposal and for allowing his technician, Mrs Jill Unsworth, to perform the analyses. I acknowledge the help of Professor A M Barrett and Dr S H Taylor of Leeds University School of Medicine for help with the preparation of this manuscript.

I am also grateful to Geigy Pharmaceuticals Ltd for financial assistance and to my 11 volunteers, without whom this project would not have been possible.

\section{References}

${ }^{1}$ Carruthers, M E, et al, Beta-blockers: Present Status and Future Prospects. ed W Schweizer, p 248. Berne, Hans Huber, 1974.

${ }^{2}$ Hodler, J, Beta-blockers: Present Status and Future Prospects. ed W Schweizer, p 260. Berne, Hans Huber, 1974

${ }^{3}$ Fain, J N, Pharmacological Reviews, 1973, 25, 67.

${ }^{4}$ Basil, B, Collins, R F, and Cuthbert, M F, British fournal of Pharmacology, 1973, 47, 620P.

${ }^{5}$ Basil, B, et al, British fournal of Pharmacology, 1973, 48, 198.

${ }^{6}$ Johnsson, G, Acta Pharmacologia et Toxicologia, 1975, 36, suppl No 5, p 59.

${ }^{7}$ Johnsson, G, Nyberg, G, and Sölvell, L, Acta Pharmacologia et Toxicologia, 1975, 36, suppl No 5, p 69.

${ }^{8}$ Davidson, C, et al, British Medical fournal, 1976, $2,7$.

${ }^{9}$ Dole, V P, fournal of Clinical Investigation, 1956, 35, 150.

${ }_{10}$ Trout, D L, Estes, H, and Friedberg, S J, fournal of Lipid Research, 1960, $1,199$.

${ }_{11}$ Abramson, E A, and Arky, R A, Diabetes, 1968, 17, 141.

12 Newman, R J, British Medical fournal, 1976, 2, 447.

${ }^{13}$ Lloyd-Mostyn, R H, and Krikler, D M, Lancet, 1970, 2, 1040

${ }^{14}$ Lipson, M J, Naimi, S, and Proger, S, Metabolism, 1971, 20, 580

${ }^{15}$ Carruthers, M E, and Taggart, P, British Medical fournal, 1973, 3, 384.

(Accepted 8 fuly 1977)

\title{
Staging breast cancer : role of bone scanning
}

\author{
C J DAVIES, P A GRIFFITHS, B J PRESTON, A H MORRIS, C W ELSTON, R W BLAMEY
}

British Medical fournal, 1977, 2, 603-605

\section{Summary}

Bone scans using technetium-99m phosphate complexes and a rectilinear scanner were carried out on 192 women with primary operable breast cancer four to six weeks after operation. The lymph node status of all these patients was assessed histologically from triple node biopsy specimens. Only nine patients had positive scans, although 94 patients had histological evidence that the tumour had already spread beyond the confines of the breast.

Bone scanning, although accurate as a prognostic guide, is helpful only in a very few cases, and serves mainly to confirm prognostic information obtained more simply and less expensively by histological examination of lymph node biopsy specimens.

Department of Surgery, University of Nottingham, Nottingham

C J DAVIES, BM, FRCS, Cancer Research Campaign surgical research fellow

$R$ W BLAMEY, MD, FRCS, reader in surgery

General Hospital, Nottingham

B J PRESTON, FRCSED, FRCR, consultant radiologist

City Hospital, Nottingham NG5 1PD

C W ELSTON, MD, MRCPATH, consultant histopathologist

P A GRIFFITHS, PHD, principal physicist

A H MORRIS, FRCR, consultant radiologist

\section{Introduction}

Many women presenting with apparently early "curable" breast cancer die prematurely from their disease." Such women probably have foci of disseminated carcinoma at the time of their primary treatment. There is an urgent need to be able to detect spread of the tumour beyond the confines of the breast, as an essential prerequisite of any plan of treatment is the accurate staging of the disease. If there is evidence of disease beyond the confines of the breast local treatment of any sort is unlikely to influence the outcome with respect to survival.

The study reported here was designed to assess the contribution that bone scanning can make to the original assessment of a patient with apparently early carcinoma of the breast. We attempted to answer the following questions: Does bone scanning help to stage the disease ? Is it a reliable prognostic guide? How useful is it compared with that method of staging based on lymph node histology?

\section{Patients and methods}

One hundred and ninety-two patients with primary operable breast cancer were studied. They presented over a three-year period at the breast clinic of the university department of surgery in Nottingham. Patients presenting with locally advanced breast cancer for whom mastectomy was thought to be inappropriate were excluded from this series. Although the patients were not staged by the TNM classification, the excluded group broadly corresponded to patients with T3 lesions. Patients who, because of age and tumour site, were treated by a wide local excision of the tumour rather than by mastectomy were also excluded.

The surgical treatment took the form of a standard simple mastectomy with triple node biopsy. After the breast had been removed, lymph nodes were sampled from $(a)$ the low axilla just below the lateral border of pectoralis minor; $(b)$ the apex of the axilla, which was 